\title{
Savitri by Sri Aurobindo: Beacon of Hope for Women in Modern Age
}

\author{
Bharati Chandrayan and Madhurima Srivastava \\ Department of English and Foreign Languages, Faculty of Engineering and Technology, SRM \\ Institute of Science and Technology, Delhi-NCR Campus, Modinagar, Ghaziabad, UP, India
}

\begin{abstract}
Sri Aurobindo was a famous philosopher and Yogi of the twentieth century. His creative contribution to the country was not limited to the certain periphery of the life. Hardly any aspect of life might be felt untouched from the scholastic donation of the seer Sri Aurobindo. Each literary work was written with the sublime intention to let world find the solution of entanglements of life. In the contemporary arena of time the existence of female has become challenging and the female class is presumed often the less deserving and women are devoid of many more equal opportunities. In span of a time after Independence many drastic changesoccurred but still female class is lagging behind and at different front of life women become the victims of situations. The dominance of male has kept the female withered before blossoming and pervading real fragrance. Each time when a woman finds herself in disadvantageous situation, her eyes are shading tears and like to narrate untold story. Her heart is brimming over with the situation. The supreme causes are because of the patriarchal approach of mind and this is the state of mind which ceases the society to practice uniformity and to discard partiality. In the current scenario if women are inspired to follow woman like Savitri who descended on the earth in form human body to liberate shackles of superstitions and prejudices of female caliber and capacity. Savitri is epitome of women power who dared to wage war with the death of God and forced Him to return the life of her husband. The stamina and strength showed by her was sign of the power of a woman and how she proved herself vindictive and the conqueror .She had created a history that is to be printed and inscribed in pages of history for forever. Savitri is the heroine of the great epic poem "Savitri" composed by the great philosopher Sri Aurobindo and this long poem hides the sublimity of philosophy of life, yogic sadhana, woman empowerment and the divinity inside woman soul that needs to be transformed to change the mode of time for the sake of changes.
\end{abstract}

KEY WORDS: WOMEN EMPOWERMENT, PATRIARCHY, AUROBINDO'S LIFE PHILOSOPHY, SAVITRI.

\section{INTRODUCTION}

The modern era is the sign of development and progress and in this particular frame of time the issue of woman empowerment is raised. How can the society prove itself as the developing and developed one? This leaves the evidence that our society in the modern era is still lagging behind and to reform the scenario. The scholars used pen and paper to bring the sensational point in limelight .For example the genius writer and philosopher Sri Aurobindo composed the largest poem 'Savitri' and

Biosc Biotech Res Comm P-ISSN: 0974-6455 E-ISSN: 2321-4007

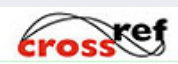

Identifiers and Pagination

Year: 2021 Vol: 14 No (8) Special Issue

Pages: 233-235

This is an open access article under Creative

Commons License Attribn 4.0 Intl (CC-BY).

DOI: $h t t p: / / d x$.doi.org/10.21786/bbrc/14.8.54 the character Savitri is leading and representing power and mightiness of a woman. This is always opined that woman is dependent creature and the shadow of male is mandatory to move in the society .The view is not much helpful for woman class and it demotivates .If in this respect the theme and concepts of Savitri is analyzed, this is found that as the representative of female she is the bundle of power and energy .That enabled her to fight against the destiny and conquered the war with God of Death Yama. She proves that woman can unfurl herself without anyone's assistance. She is born in human body as the savior.

The omniscient Goddess leaned across the breadths That wrap the fated journeying of the stars

And saw the spaces ready for her feet.

Once she half looked behind for her veiled sun, Then, thoughtful, went to her immortal work.

Earth felt the Imperishable passage close:

\section{Article Information}

Received:08 $8^{\text {th }}$ June 2021

ccepted after revision: $25^{\text {th }}$ July 2021 
The waking ear of Nature heard her steps And wideness turned to her its limitlesseye,

And, scattered on sealed depths, her luminous smile Kindled to fire the silence of the worlds

(The Book of Beginning Savitri: page 26)

Patriarchy is instilled in the blood of Indian society and first of all this needs to be uprooted from it. The approach refers to the male-dominance and hinders the growth of female. This insensible approach starts from family and it finally grips female with the acceptance of the degraded status and it stars to paralyze the mind . The mind is not in the state to feel and recognize its own status and caliber. The impact of patriarchy is not deniable in modern era. Partiality and discrimination are general phenomena of daily life. Existing cause is persisting with female gender. This class has underestimated the power and potential .The class is not retaliating and voicing together. The great poetic creation 'Savitri' is proved as a great tool to revolutionize and sensitize and it awakens woman to identify her mightiness and untold power. The paper reports that how Savitri has become the Beacon of hope for modern generation of woman.

The daily oblation of her unwept tears

All the fierce question of man's hours relieved. The sacrifice of suffering and desire

Earth offers to the immortal Ecstasy Began again beneath the eternal Hand

Awake she endured the moments' serried march and looked on this green smiling dangerous world, And heard the ignorant cry of living things.

Amid the trivial sounds, the unchanging scene Her soul arose confronting Time and Fate.

Immobile in herself, she gathered force. This was the day when Satyavan mustdie.

(The Book of Beginning Savitri: Page 32)

It was decided twelve months back that Satyavan must die. Knowingly Savitri took the decision to marry with him. Her mother was anxious from the decision and her mother requested God Narada to convince her to change the decision. Savitri proclaimed that there was no anotherthought to change the decision .She declared that she would not change whereas she was determined to change the destiny and would have planned to face the upcoming challenges of her husband's life.

To wrestle with the Shadow she had come And must confront the riddle of man'sbirth

And life's brief struggle in dumb Matter's night Whether to bear with Ignorance and death

Or hew the ways of Immortality, To win or lose the godlike game for man, Was her soul's issue thrown with Destiny's dice

(The Book of Beginning, Savitri: Page 38) The Mother, saintly lady names 'Savitri' as a form of woman power, the following lines justify.

"I am stronger than death and greater than my fate" (490)

And "Her will must cancel her body's destiny" (15).
Savitri firstly planned to attain spiritual power and to develop her to the level where supra- mental power is supposed to descend in her and the evolution of her physical and spiritual power will start fostering forth .The realization of God-Head in body is the sign of spiritual power. She started practicing oblations, rigorous fast and tapsya equipped herself with the abundance of spiritual power. She waged the war in which one side being the representative of woman she was standing and on the other side the symbol of male the Death of God was taking the command.

Sri Aurobindo as a Yogi had realized that our country after independence is not free of shackles of thoughts and left woman and man tied with certain thoughts. The woman is not being given liberty and the system is absolutely getting harassed by the approach of male-dominance. Savitri, the story is the small part of the Mahabarata is undoubtedly the great inspiration of woman-life. The representation of Savitri is the declaration of the mightiness and strength. Yama is supposed to represent the male dominance. It was shown in the poem that the power of womanunderestimated by someone is the sign of an ultimate oblivious act and the assumption related to woman power out beats males.

The episode of the stressful journey of Savitri leaves the marks on sands of annals. The knowledge and wittiness of woman is not credited equally as the males are rewarded in our surroundings. The similar thought process is standing with The God of Death and He assessed her power lesser and repeatedly convinced not to follow in the dark journey from where no one can return. Savitri, the representative of woman power continuously is working on her goal that was to bring life into her husband's body. She won the war and successfully achieved what she had planned .The example set by Savitri is proved as the motivational tool for the woman of twentieth and twenty first century. The Epic poemundoubtedly made the woman awake to fight for their restoration of image in the society. TheGoddess joined human body with the supreme motive of igniting the slept and dormant mode. The consciousness and knowledge in every aspect of woman pays the remarkable values.

Women are still sentenced in the slavery. Slavery means that woman remains captives of conservative thought process of our society. So to reform the system, the magic of pen always proved .In modern time, every time when the evolution has stuck between spirituality and matter. Sri Aurobindo favored the absolute solution that is not only the physical evolution but holistic concept of evolution. The evolution and vertical growth of human being can eliminate any sort of partial approach and healthy nation with the strong balance of both genders can be dreamt and transformed into reality. Real evolution is to move towards Godhead and attempt to let the god-head lean towards earth.

The sign of evolution is supposed to be felt widely. Conservative and short term goal is discarded and is 
thought not only for the sake nation but the wide vision of Unity. Savitri is measured from different aspects of life where she presented the role of a dedicated and loyal wife also. If this is analysed, many naked and malicious images of modernity of women are realized. The lessons of loyalty, sacrifices and dedication all are helpful in married life. In modern era we have forgotten ourselves. The divine love for her husband and vice versa enabled her to continue arguments and in the session of the war waged with Lord Yama introduced the invincible power of woman and her patience to plan strategically for the attainment of goal. In the current scenario many cases and legal feuds in married life are filed and sorted out in the court. The situation reveals that the unconditional love between husband and wife is getting arid and the concealed spirituality and dedication have been lost .Savitri is the epitome of power and the symbol of womanhood of modern era.

\section{CONCLUSION}

This paper successfully is designed with the sublime goal to end patriarchal approach from the society and minimizes the graph of crime against them .Savitri declares herself as a sign of all powers. This is a big reminder to accumulate power Iwhen this is needed. Woman Empowerment word is repeatedly stressed to let the woman enjoy the liberty as the opposite sex practices. The character Savitri is just the example cited by the Yogi and sage Sri Aurobindo to ignite the dormant state of mind of woman. This is visibly observed that woman is named as the weaker sex. Is this the correct naming of female sex? The Hindu Mythologies are the proved evidences and the contribution of woman in the reformation through the battle and the war is clearly mentioned in the great epics and the treatises. The Goddess Savitri's birth is lesson to the human how the impossible can be converted into possible.

The declared truth of Satyavan's life has not stopped her and diverted her mind. The power engrossed in her mind and soul declares her the conqueror and her dedicated approach towards that is renamed 'Sadhana' has filled her with tremendous power. A great number of cases of sexual assault, rapes, psycho torture, economic suppression and inequality issues are reported with the hope of speedy help. The focal point is why and how such situations appear with woman this unsaid pain caused by the patriarchal approach is not strengthening and building up the current society. The dominance approach of male needs to be discarded since the estimated repercussion of the suppressed class may burst into fire and society may never rise. The decaying values of our society may never fructify. The alarming data of India $2018,33,356$ cases of rape were reported and some of the victims fell intoutmost depression and their life turned into unsmooth darkness.
According to the National Crime Bureau Data, 50 percent victim's age ranges between 18 to 30 and the instrumental people are always known to them. In India woman is not only succumbed to the penetrating situation but this sort of prevailing male dominance has pervaded worldwide. That is reported that every.second an American lady is as saulted and one out of six is the victim of such in hygienic situation of the society. The young girls are withered before budding out into the excellent life. The survey completed by the American team and brought to our knowledge how such situations paralyzes woman has forced to think as own self as the dependent one. The authors, poets and learned people may peep into our inside and have the scholastic plan to give the permanent solution with the literary weapon of poems, stories, and etc. Sri Aurobindo has jolted the society and his poetry Savitri ushered the modern era to believe the power of woman. Goddess Savitri has waged the war with one Yama, God of the Death ,nowadays at every point there is the Yama and woman is suggested to accumulate the power and to equip herself to unfurl the flag of success.

\section{REFERENCES}

Caputo, John. "On not Circumventing the Quasitranscendental: The Case of Rorty and Derrida," in Gary

"Death" and "Violence" in MitraPhukan's Writings: Unraveling an Aesthetics of Pain in The Collector's Wife and Hope NamrataPathak

Deconstruction in a Nutshell: A Conversation with Jacques Derrida. New York: Fordham University Press, 1997

Hall, Stuart. (1997) Representation, Cultural Representations and Signifying Practices London: Sage Publications.

https://www.indiatoday.in/india/story/rapes-in-indiaoffenders-victim-minor-data-ncrb-1635691- 2020-0110

https://www.rainn.org/statistics/victims-sexualviolence

https://www.sriaurobindoashram.org/

Johnson, M. (1988) Strong Mothers, Weak Wives: The Search for Gender Equality

Maddison (ed.), (1993) Working through Derrida. Evantson, IL: Northwestern University Press, pp. 14769.

Pateman, C. (1988) The Sexual Contract. Cambridge: Polity Press.

Sri Aurobindo, Life divine, vol. 12

Sri Aurobindo, The Future poetry, vol. 5

Sri Aurobindo, The Supramental Manifestation and other writings, vol. 20

Sri Aurobindo, Thoughts and glimpses, p.18

Synthesis, of Yoga, volume 13

www.savitri.net.in 